\title{
Antioxidant, Antibacterial and Antitumor Activity of Ethanolic Extract of the Psidium guajava Leaves
}

\author{
Tatiane Vieira Braga ${ }^{1}$, Rosana Gonçalves Rodrigues das Dores ${ }^{2}$, Camila Soncin Ramos ${ }^{2}$, \\ Fernanda Cristina Gontijo Evangelista ${ }^{3}$, Letícia Márcia da Silva Tinoco ${ }^{4}$, \\ Fernando de Pilla Varotti ${ }^{3}$, Maria das Graças Carvalho' ${ }^{1}$, Adriano de Paula Sabino ${ }^{1}$ \\ ${ }^{1}$ Federal University of Minas Gerais, Belo Horizonte, Brazil \\ ${ }^{2}$ Federal University of Ouro Preto, Ouro Preto, Brazil \\ ${ }^{3}$ Federal University of São João Del Rei, Divinópolis, Brazil \\ ${ }^{4}$ Pitágoras Faculty, Belo Horizonte, Brazil \\ Email: ${ }^{*}$ tativbr@gmail.com
}

Received 25 September 2014; revised 23 October 2014; accepted 6 November 2014

Copyright @ 2014 by authors and Scientific Research Publishing Inc.

This work is licensed under the Creative Commons Attribution International License (CC BY). http://creativecommons.org/licenses/by/4.0/

c) (i) Open Access

\begin{abstract}
Psidium guajava L. has extensive use in folk medicine. The aim of this study was to quantify the levels of phenolic, flavonoids, antioxidant activity, leathality assay and antibacterial and antitumoral activities of the extract of $P$. guajava. In the dry guava extract there were high levels of phenolics $(766.08 \pm 14.52 \mathrm{mg} / \mathrm{g})$, flavonoids $(118.90 \pm 5.47 \mathrm{mg} / \mathrm{g})$ and antioxidant activity $(87.65 \%)$. The $\mathrm{LD}_{50}$ was $185.15 \mu \mathrm{g} / \mathrm{ml}$. The MIC value was $250 \mu \mathrm{g} / \mathrm{ml}$ for Streptococcus mutans, Streptococcus mitis and Streptococcus oralis. $\mathrm{IC}_{50}$ of the extract tested in the HeLa, RKO and Wi cell lines was 15.6 $\pm 0.8 \mu \mathrm{g} / \mathrm{ml}, 21.2 \pm 1.1 \mu \mathrm{g} / \mathrm{ml}$ and $68.9 \pm 1.5 \mu \mathrm{g} / \mathrm{ml}$, respectively. The results of all analyses allow us to conclude that the dry extract of guava leaves has promising activity to be applied topically in the oral cavity or in the development of antitumor formulation or even be used as a functional food.
\end{abstract}

\section{Keywords}

Guava, Antitumor, Medicinal Plants, Functional Foods

\section{Introduction}

The insertion of medicinal plants in disease treatment by the Brazilian population is rooted in regional traditions

${ }^{*}$ Corresponding author. 
that are transmitted to future generations, by oral reports, family histories, rituals, or homemade preparations. In this sense, research on medicinal plants was performed based on the ethnopharmacological knowledge, as the proposal of this work, in which was evaluated the antioxidant and antibacterial action and antitumor properties of guava leaves.

Psidium guajava L. (Myrtaceae), native to tropical America is commonly known as guava or guajava or guava tree. It is a small tree, with globous or piriform fruits, yellow, $3-6 \mathrm{~cm}$ in diameter. Different parts of the plant are used in folk medicine in the treatment of diseases such as wounds, lesions, ulcers, diarrhea, cholera, hypertension, obesity and the control of Diabetes mellitus [1]. In India, the young leaves are used as antitussive. In China, the leaves are used as anti-inflammatory and hemostatic agent. The decoction of the leaves is used in the treatment of cholera, diarrhea and vomiting reduction [2] [3]. In Brazil, the leaves are popularly used in the treatment of gastrointestinal disorders, practice inherited originally, of the Aztec medicine of Mexico [4]. In leaves, the chemical compounds detected are tannins, flavonoids (myricetin, quercetin, luteolin and kaempferol), essential oils (caryophyllene, nerolidiol, $\beta$-bisabolene, aromadendrene, $\mathrm{p}$-selinene, $\alpha$-pinene and 1,8-cineol), triterpenoids (oleanic acid, ursolic acid, catecolic acid, guayavolic acid, maslinic acid, ellagic acid) and $\beta$-sitosterol [5] [6]. It has significant quantities of fatty acids and pectins [7].

Several studies have investigated the properties of natural products as antioxidants, antibacterial, anticariogenic, chemopreventive and antitumor. These are stimulated, mainly due the toxic effects produced by synthetic antioxidants used in industry [8], drug resistance, or the search for new substances that act against bacterial growth and biofilm formation [9]-[11]. In general, the antioxidants are characterized as substances present in low concentrations compared to oxidizable substrate, which significantly retard or inhibit oxidation of the substrate. Phenolic compounds have received attention, mainly by lipid peroxidation and lipoxygenase inhibition [12]. Terpenes and flavonoids are important antibacterial and anticariogenic agents. Dental caries is a common chronic disease which affects from $60 \%$ to $90 \%$ of young population. The formation of dental plaque, which plays an important role in the development of caries and periodontal disease in humans, can be initiated by several strains of oral streptococci [10] [13]. Streptococcus mutans, Streptococcus mitis and Streptococcus oralis are involved in the formation of dental caries. The process involves bacterial adhesion, biofilm formation, and tooth enamel demineralization by acids produced by microorganisms [14] [15]. Flavonols, mainly quercetin and kaempferol derivatives, present in guava, have been commonly found in natural products. Although their functions have been overall related with antioxidant properties, they also show an anticancer activity based in the induction of apoptosis and/or arrest of tumoral cells [16]. Although most flavonoids appear to be non toxic to humans and animals, they have been demonstrated to inhibit proliferation in many kinds of tumors cell lines. Quercetin has antiproliferative effects on squamous cell carcinoma HTB43, meningioma cells, colon cancer cells, Caco-2 and HT-29, with a dose-dependent effect. Flavonoids also have shown inhibitory effects on the growth of leukemia HL-60 cell, with an IC $_{50}$ value ranging from 10 to $940 \mathrm{ng} / \mathrm{ml}$ [17]. The study by Sato [18] found that the leaves of Psidium guajava may have anticancer activity, although it was based on limited studies. Development of new anticancer agents is vital because cancer has been the second leading cause of death in the world population. The cancer was responsible to 7.6 million deaths in 2005, will cause 9 million in 2015 and over 11 million deaths in 2030 [19].

The aim of the present study was to assess antioxidant, antibacterial and antitumor activity of ethanolic extract of the Psidium guajava leaves.

\section{Materials and Methods}

\subsection{Reagents}

Tannic acid, quercetin, lapachol, 1,1-diphenyl-2-picryl-hydrazyl (DPPH), butylhydroxyanisole (BHA), FolinCiocalteau reagent, vanillin, RPMI (Roswell Park Memorial Institute Medium), dimethyl sulfoxide (DMSO), chloramphenicol were purchased from Sigma-Aldrich (Germany/EUA). Ethanol, methanol, hydrochloric acid, $\mathrm{Na}_{2} \mathrm{CO}_{3}$, eugenol, 2,3,5-triphenyltetrazolium chloride were acquired from VETEC (Brazil). Brine shrimp A. salina was obtained from Artemia Salina $\mathrm{RN}^{\circledR}$ (Brazil). Artificial sea water was of Nature’s Ocean (Brazil). Strains of streptococcus were provided by the laboratory of microorganisms reference the Instituto Nacional de Controle de Qualidade em Saúde (INCQS/FIOCRUZ), Brazil. 3-(4,5-dimethyl-2-thiazolyl)-2,5-diphenyltetrazolium bromide (MTT or thiazolyl blue tetrazolium bromide) were used of the Invitogen (EUA), fetal calf serum (FBS) of 
Gibco (EUA). Other reagents used were analytical purity.

\subsection{Extraction and Artemia salina Lethality Assay}

Stems with leaves of guava in two distinct stages of maturation, young in early development and adult fully expanded were collected in July 2013 in Ouro Preto, Minas Gerais, Brazil. Voucher specimen was deposited in the Herbarium José Badini of Federal University of Ouro Preto, registered with number OUPR 27242.

The ethanolic extract was made according to the general methods of the Farmacopéia Brasileira V [20]. Successive re-extractions were made until the exhaustion of the plant drug. After the extraction, the filtrate was evaporated on a water bath of $35^{\circ} \mathrm{C} \pm 2{ }^{\circ} \mathrm{C}$ of the solvent to dryness. The dry extract obtained (DEG) was weighted and the yield was calculated based on the initial fresh weight and the proportion of dry extract obtained (\%). Standardization of organoleptic quality (color, odor and flavor) and physic-chemical analysis (pH and dry residue) were made to the extract [20].

The Artemia salina lethality assay procedure was adapted from Favilla [21] observed the experimental and environmental conditions. Brine shrimp eggs were obtained from a local aquarium store and hatched in glass tubes containing artificial sea water (38 g/l) in distilled water and incubated with artificial lighting (60 W lamp) at $24^{\circ} \mathrm{C} \pm 1^{\circ} \mathrm{C}$ for $48 \mathrm{~h}$. After this period, the newly hatched brine shrimps (nauplii) were separated and transferred to fresh sea water with a Pasteur pipette and immediately used for bioassays. Dry extract (DEG) at concentrations of 10,100, 500 and $1000 \mu \mathrm{g} / \mathrm{ml}$ were transferred into a glass tube, resuspended in $5 \mathrm{ml}$ of sea water, homogenized and added to the 10 brine shrimps, previously separated. Lapachol standard was used in the same concentrations of extract as positive control. Untreated control (seawater + Artemia) was analyzed together with the concentrations of DEG and Lapachol. The tubes were kept under constant irradiance and average temperature of $24^{\circ} \mathrm{C} \pm 1^{\circ} \mathrm{C}$, by $24 \mathrm{~h}$. All tests were conducted in four replicates for all treatments (DEG, lapachol and untreated). The mortality endpoint for this bioassay was defined as the absence of forward motion of shrimps. The Probit analysis method was used for the calculate $\mathrm{LD}_{50}$ according to the Farmacopéia Brasileira V [20].

\subsection{Phenolic, Flavonols Content and Antioxidant Activity}

The total phenolic content of DEG was determined according to the Folin-Ciocalteu method, adapted of Singh, Chidambara-Murthy \& Jayaprakasha [22]. Four replicates of $1 \mathrm{mg}$ of DEG were mixed with $2.0 \mathrm{ml}$ of 10 -folddiluted Folin-Ciocalteu reagent and $1.6 \mathrm{ml}$ 7.5\% sodium carbonate $\left(\mathrm{Na}_{2} \mathrm{CO}_{3}\right)$ solution. Blank was prepared by adding $2.0 \mathrm{ml}$ of 10 -fold-diluted Folin-Ciocalteu reagent and $1.6 \mathrm{ml} 7.5 \%$ sodium carbonate $\left(\mathrm{Na}_{2} \mathrm{CO}_{3}\right)$ solution. The absorbance at $765 \mathrm{~nm}$ was measured after 30 minutes at room temperature $\left(21^{\circ} \mathrm{C}\right)$. The total phenolic content was calculated according to the standard curve prepared with tannic acid and the results were expressed as milligrammes of tannic acid equivalents (TAE) per gramme of solid extract.

Total flavonols contents of DEG extract was determined by the procedure adapted of Jayaprakasha, Singh \& Sakariah [23]. The amount of total flavonols was assayed by the vanillin method (colorimetry). Four replicates of $40 \mathrm{mg}$ of DEG were added to $2.5 \mathrm{ml}$ of $4 \% \mathrm{HCl}$ in ethanol and $2.5 \mathrm{ml}$ of $1 \%$ vanillin in ethanol. Blank was prepared by adding $2.5 \mathrm{ml}$ of $4 \% \mathrm{HCl}$ in ethanol and $2.5 \mathrm{ml}$ of $1 \%$ vanillin in ethanol. The absorbance at $500 \mathrm{~nm}$ was measured after 20 minutes in the dark at room temperature $\left(21^{\circ} \mathrm{C}\right)$. The total flavonols content was calculated by a standard curve prepared with quercetin and the results were expressed as milligrammes of quercetin equivalents (QCT) per gramme of solid extract.

The potential antioxidant activity of the extract was assessed on the basis of the scavenging activity of the 1,1-diphenyl-2-picryl-hydrazyl (DPPH) free radical. Four replicates of $40 \mathrm{mg}$ of DEG was added to $2 \mathrm{ml}$ of methanol and shaken vigorously, $1 \mathrm{ml}$ of $0.1 \mathrm{mM}$ methanolic solution DPPH was added to these tubes. BHA (Butylhydroxyanisole) positive control was prepared under the same conditions described for the extract. The negative control was prepared using $0.1 \mathrm{mM}$ methanolic solution of DPPH. Methanol was used for the baseline correction. Absorbance was measured at $520 \mathrm{~nm}$, at room temperature $\left(23^{\circ} \mathrm{C}\right)$, in times of 0 and 30 minutes. Radical scavenging activity was expressed as the inhibition percentage and was calculated using the following formula: AAT\% $=($ Abs control $-($ Abs sample/Abs control $)) \times 100[22]$.

\subsection{Antibacterial and Antitumor Activity}

The microorganisms used were lyophilized strains of Streptococcus mutans (ATCC 25175), Streptococcus mitis 
(ATCC 49456) and Streptococcus oralis (ATCC 10557), assigned by the laboratory of microorganisms reference of the Instituto Nacional de Controle de Qualidade em Saúde (INCQS) belonging to Fundação Osvaldo Cruz (FIOCRUZ), Brazil. Microorganisms were grown on blood agar at $37^{\circ} \mathrm{C}$ for $24 \mathrm{~h}$. The obtained cell mass was collected aseptically with sterile loop and was suspended in tubes containing $10 \mathrm{ml} 0.85 \%$ sterile saline solution. The inoculum was prepared with approximately $10^{6}$ colony forming units per $\mathrm{ml}(\mathrm{CFU} / \mathrm{ml})$, equivalent to grade $0.5 \mathrm{McF}$ arland and was used to evaluate the antibacterial activity by disc diffusion and minimum inhibitory concentration (MIC).

Evaluation of antibacterial activity was performed by disk diffusion method according to the Clinical and Laboratory Standart Institute protocol [24]. The inoculum was seeded in petri dishes with Mueller-Hinton agar and later the paper disks impregnated with $10 \mu \mathrm{l}$ of the extract DEG $(50 \mathrm{mg} / \mathrm{ml})$ were applied. The negative control used was ethanol PA and the positive control was chloramphenicol $(30 \mu \mathrm{g})$. The plates were incubated at $37^{\circ} \mathrm{C}$ for $24 \mathrm{~h}$ proceeded to read $(\mathrm{mm})$ of inhibition zones of bacterial growth. The tests were performed in triplicate.

The minimum inhibitory concentration (MIC) was determined according to the Clinical and Laboratory Standart Institute protocols [25]. This test was performed in sterile 96-well microplates. In each well was added 100 $\mathrm{mL}$ of inoculum standardized in $0.5 \mathrm{McF}$ arland and $100 \mu \mathrm{l}$ of DEG has been previously solubilized in DMSO and diluted in Mueller-Hinton broth. DEG was tested in serial dilution from $1000 \mu \mathrm{g} / \mathrm{ml}$. Positive control used was Eugenol. One well with specific medium and microorganism was used as control of the growth, and one well was inoculated with the broth only to check the sterility of the media and the aseptic work conditions. The microplates were prepared in triplicate and incubated anaerobically at $37^{\circ} \mathrm{C}$ for $24 \mathrm{~h}$. After incubation, bacterial growth was evaluated adding in each holes $20 \mu \mathrm{l} 0.5 \%$ TTC (2,3,5-triphenyltetrazolium chloride) aqueous solution. The microplates were incubated again for another 3 hours at $37^{\circ} \mathrm{C}$. After this final incubation, the presence of red color in the holes indicated bacterial growth. The MIC was defined as the lowest concentration of the extract $(\mu \mathrm{g} / \mathrm{ml})$ able to prevent bacterial growth.

The principle of this method consists of the absorption of salt MTT by the cells that is reduced within the mitochondria to formazan product. This product accumulated inside the cell, is extracted through the addition of solvent DMSO [26]. Evaluation of antitumor activity was done with human cell lines HeLa (cervical carcinoma ATCC CCL2), RKO-AS45-1 (colorectal carcinoma ATCC CRL-2579) and Wi-26VA4 (lung fibroblast ATCC CCL-95.1). The 96-well microplates was plated with $1 \times 10^{6} \mu \mathrm{l}$ cells, homogenized in RPMI 1640 medium supplemented with fetal bovine serum (FBS) and penicillin-streptomycin antibiotics. After cell plating, microplates were incubated at least $24 \mathrm{~h}$ at $37^{\circ} \mathrm{C}, 5 \% \mathrm{CO}_{2}$, followed by the addition of DEG and quercetin solubilized in DMSO 1\% (v/v). Negative controls were cells without treatment. Eight serial dilutions (1:10) from stock solution $(10 \mathrm{mg} / \mathrm{ml})$ using RPMI supplemented with $1 \%$ FBS were used. Cell viability was evaluated after incubation for $48 \mathrm{~h}$, by removing and discarding the medium and addicting $100 \mu \mathrm{l}$ MTT 5\%, followed by in additional incubation for $3 \mathrm{~h}$. The supernatant was removed and discarded and the insoluble formazan product was dissolved in DMSO. Then, optical density (OD) of 96-well was measured using spectrophotometer microplate reader at $550 \mathrm{~nm}$. The OD of formazan formed in untreated control cells was taken as $100 \%$ of viability. All assays were performed in triplicate [27].

\subsection{Statistical Analysis}

SAEG (7.0 Viçosa: Fundação Arthur Bernardes, UFV/DBG, 2013) software was used to perform analyses and standard curves. Mean results of brine shrimp mortality were plotted against the logarithms of concentrations using Probit Analysis which median lethal concentrations $\left(\mathrm{LD}_{50}\right)$ at $95 \%$ confidence intervals [20]. The $\mathrm{IC}_{50}$ curves were elaborated using the program OriginPro 8.0 (OriginLab Corporation, Northampton, MA, USA).

\section{Results and Discussion}

\subsection{Extraction and Artemia salina Lethality Assay}

The procedure to obtain the ethanol extract of fresh leaves guava by re-maceration had the yield of 36.91\% DEG. This percentage can be considered high when correlated to the water content found in young leaves $(\mu=59.87 \%$ $\pm 1.84 \%)$ and mature leaves $(\mu=59.52 \% \pm 2.29 \%)$ and also when compared to yield of guava leaves extract, dried in forced ventilation oven $(\mu=20.01 \% \pm 0.12 \%)$ [28]. In the standardization of organoleptic and physi- 
co-chemical quality DEG remained dark green color, woody odor, extremely astringent taste, $\mathrm{pH}=6$ and 2.23\% desiccation residue (dry residue).

By means of probit analysis, toxicity values were calculated for leaves of P. guajava using Artemia salina test. The $\mathrm{LD}_{50}$ for leaf extract was $185.15 \mu \mathrm{g} / \mathrm{ml}$ and lapachol was $22.74 \mu \mathrm{g} / \mathrm{ml}$. Lapachol is natural product with known anticancer properties, anti-inflammatory, analgesic, antibiotic, antimalarial, anti-trypanosome, antiulcer and regarded as relatively high toxicity [29]. The assay is considered a useful tool for preliminary assessment of toxicity [30]. In toxicity evaluation of plant extracts by brine shrimp bioassay, an $\mathrm{LD}_{50}$ value lower than 1000 $\mu \mathrm{g} / \mathrm{ml}$ is considered bioactive [31]. In this study the extract had $\mathrm{LD}_{50}$ value $<1000 \mu \mathrm{g} / \mathrm{ml}$, therefore, the can have biological activity. The results, compared with literature data, demonstrated safety in the use of ethanol extract of guava leaves.

\subsection{Phenolic, Flavonols Content and Antioxidant Activity}

The content of phenolic compounds in ethanol extract of guava was determined relative to the standard curve of tannic acid $\left(\hat{y}=0.0342 \mathrm{x}-0.156 ; \mathrm{r}_{2}=0.9987\right)$. The total amount of phenolic compounds was $766.08 \pm 14.52$ $\mathrm{mg} / \mathrm{g}$. It's important to remember that guavas tree have high levels of tannins, responsible for the astringent character of its fruit and leaves. Qian e Nihorimbere [32] evaluated phenolic content of aqueous and ethanol extract of guava leaves, and achieved the levels of $575.3 \pm 15.5 \mathrm{mg} / \mathrm{g}$ ethanol extract and $511.6 \pm 6 \mathrm{mg} / \mathrm{g}$ aqueous extract by gram of dry extract, amounts considered by the authors as too high.

In the determination of flavonols, quercetin was used as standard $\left(\hat{y}=0.0039 x-0.0024 ; r_{2}=0.9998\right)$. The content of flavonols was $118.90 \pm 5.47 \mathrm{mg} / \mathrm{g}$. According Tasca [33] the percentage of flavonoids in fruits of guava cv. Paluma represent about $13 \%$ (125.22 $\mathrm{mg}$ to $187.41 \mathrm{mg}$ rutin/100g) and total phenolic content was $1047.55 \mathrm{mg} / \mathrm{g}$ to $1462.86 \mathrm{mg} / \mathrm{g}$ gallic acid, which allows us to infer that there are high levels flavonols and phenolic compounds in the leaves of this study. The content of bioactive compounds varies depending on biotic and abiotic factors not have been observed structural changes in chemical composition, but changes in percentage of majority compounds. The time for collecting the leaves may have promoted these higher levels, because in mature leaves, the greatest concentrations of flavonoids were found in July, myricetin (208.44 mg/kg), quercetin (2883.08 mg/kg), luteolin (51.22 mg/kg) and kaempferol (97.25 mg/kg) [6].

Qian e Nihorimbere [32] assume that is the combination of high concentrations of tannins and flavonoids responsible for the antidiarrheal action. Was identified by HPLC, the extract of guava leaves, peaks that correspond to the derivatives of quercetin (Quercetin-3-O-rhamnoside, $\mathrm{C}_{15} \mathrm{H}_{10} \mathrm{O}_{7}$ ) which acts pharmacologically as a potential antioxidant agent. Quercetin also has anti-inflammatory, antiviral and antitumor actions in addition to inhibiting aldose reductase [1].

The potential antioxidant activity of the ethanolic extract of $P$. guajava showed a high effective free radical scavenging in the DPPH assay. This method is based on the capture of DPPH by antioxidants producing a decrease in absorbance. The increased consumption of DPPH by a sample is proportional to increased antioxidant activity [8]. The average antioxidant activity of the ethanol extract of guava leaves was $68.15 \% \pm 5.34 \%$ (time zero minute) and $87.65 \% \pm 6.30 \%$ (time 30 minutes) compared to BHA (antioxidant reference) $(\hat{y}=0.6502 \mathrm{x}+$ $\left.68,148, r_{2}=1\right)$. These levels are considered high for leaves and can be correlated with the levels of flavonols and phenolic compounds. These high values, allows us to infer that the ethanol extract of leaves of guava (Psidium guajava L.) may have thermogenic potential or can be used as functional food. After pharmacological studies, guava extract may play a key role in preventing cardiovascular disease, cancer and degenerative diseases, due to the high antioxidant potential. Is important to remember that natural antioxidants occur in all parts of plants. These antioxidants include carotenoids, vitamins, phenols, flavonoids, dietary glutathione, and endogenous metabolites. Several studies have revealed that the phenolic content in the plants are associated with their antioxidant activities, probably due to their redox properties, which allow them to act as reducing agents, hydrogen donors, and singlet oxygen quenchers [34].

\subsection{Antibacterial and Antitumor Activity}

The ethanol extract of guava leaves was effective in inhibiting the growth of S. mitis, S. mutans and S. oralis at $50 \mathrm{mg} / \mathrm{ml}$. The diameter of the inhibitory halo was greater than $8.2 \mathrm{~mm}$ (Table 1). In the evaluation of antibacterial activity by disc diffusion, the plant extract is considered active when there is formation of inhibitory halo greater than or equal to $7.0 \mathrm{~mm}$ [35]. The MIC value for the positive control (eugenol) was $250 \mu \mathrm{g} / \mathrm{ml}$ for $S$. 
mutans, and $500 \mu \mathrm{g} / \mathrm{ml}$ for S. mitis and S. oralis. The MIC value for the extract of guava was $250 \mu \mathrm{g} / \mathrm{ml}$ for $S$. mutans, S. mitis and S. oralis (Table 1), proving the effectiveness of the extract used, which was higher $(2 \times)$ or similar the eugenol, natural product, renowned as antiseptic, applied topically in the oral cavity and used as component in toothpastes and dental protective.

In another study, the treatment of the early plaque settlers with $1 \mathrm{mg} / \mathrm{ml}$ aqueous extract leaf of Psidium guajava reduced the cell-surface hydrophobicity of Streptococcus sanguinis, Streptococcus mitis and Actinomyces sp., by $54.1 \%$, $49.9 \%$ and $40.6 \%$, respectively [36]. These results provide some scientific rationale for its use in the treatment of dental diseases and suggested that guava leaf extracts may inhibit the caries-inducing properties of Streptococcus and thus may be beneficial for the dental care [6].

The use of medicinal plants and functional foods in chemoprevention seeks to prevent, reduce the incidence or assist in controlling the proliferation of cancer cells. The antitumor activities have been reported in ethnopharmacological studies as one of the numerous nutritional benefits of consuming the fruits and juice of $P$. guajava [37]. The effect of the extract $P$. guajava and quercetin on the growth of cervical carcinoma (HeLa), colorectal carcinoma (RKO-AS45-1) and lung fibroblast (Wi-26VA4) cell lines investigated by MTT assay are shown in Table 2.

According to the National Cancer Institute (USA), crude extracts are cytotoxic when their $\mathrm{IC}_{50}$ values are less than $30 \mu \mathrm{g} / \mathrm{ml}$ [38]. The extract of P. guajava showed significant antitumor activity on HeLa and RKO-AS45-1. However, Wi-26VA4 cells were the least affected by the cytotoxic effects of the extracts (Table 2). These could be because the extract were not cytotoxic to the lung fibroblast but affected cervical carcinoma and colorectal carcinoma cell.

The use of quercetin was based on the studies as Seufi [39] on the preventive effect of quercetin on hepatocellular carcinomas in vivo by RAPD-PCR methodology, where quercetin exerted preventive effect via reduction of oxidative stress and antioxidant activity. Phenolic compounds are potential chemopreventive agents especially flavonoids present in leaves of guava. Flavonoids can act through their ability to inhibit various PKs (protein kinase) inhibiting events in the signal transduction of cell proliferation by stopping the cell cycle via CDKs (cyclin-dependent kinases) by modulating the activity of MAPKs (mitogen-activated PKs) with possible anti-neurodegenerative and imumoestimulante actions. Flavonoids have been found to arrest cell-cycle progression at either G1/S or G2/M boundaries. However, the molecular mechanisms involved in cell-cycle arrest by flavonoids remain largely unclear, although the modulation of multiple cell-cycle regulatory proteins seems to be involved. Flavonoids may exert antioxidant activity and anti-inflammatory action through direct inhibition of metalloenzymes pro-oxidants (LOXs: lipoxygenases; COXs: cycloxigenases; and XO: xanthine oxidase) and inhibition of ornithine decarboxylase (induced by tumor promoters) [17] [40].

Table 1. Antibacterial activity (50 mg/ml) and minimum inhibitory concentration (MIC) of extracts of Psidium guajava L. and eugenol.

\begin{tabular}{cccc}
\hline \multirow{2}{*}{ Strain } & \multicolumn{2}{c}{ Guava extract } & Eugenol \\
\cline { 2 - 4 } & Inhibition zone $(\mathrm{mm})$ & $\mathrm{MIC}(\mu \mathrm{g} / \mathrm{ml})$ & $\mathrm{MIC}(\mu \mathrm{g} / \mathrm{ml})$ \\
\hline Streptococcus mutans (ATCC 25175) & $8.6 \pm 0.57$ & 250 & 250 \\
Streptococcus mitis (ATCC 49456) & $8.2 \pm 0.28$ & 250 & 500 \\
Streptococcus oralis (ATCC 10557) & $9.3 \pm 0.76$ & 250 & 500 \\
\hline
\end{tabular}

Table 2. Antitumor activity of alcoholic extract of leaves $P$. guajava on three human cell lines.

\begin{tabular}{ccc}
\hline Cell line & Psidium guajava L. & Quercetin \\
\hline HeLa & $15.6 \pm 0.8$ & $160.1 \pm 0.7$ \\
RKO-AS45-1 & $21.2 \pm 1.1$ & $139.4 \pm 1.2$ \\
Wi-26VA4 & $68.9 \pm 1.5$ & $92.3 \pm 0.5$ \\
\hline
\end{tabular}

The data indicate the mean of concentration producing $50 \%$ growth inhibition $\left(\mathrm{IC}_{50}\right) \mu \mathrm{g} / \mathrm{ml} \pm \mathrm{SD}$. 


\section{Conclusion}

The results of all analyzes allow us to conclude that the dry extract of guava leaves has promising activity for use in the oral cavity or in the development of antitumor formulation or even be used as a functional food.

\section{Acknowledgements}

Authors are grateful to Conselho Nacional de Desenvolvimento Científico e Tecnológico (CNPq), Fundação de Amparo à Pesquisa do Estado de Minas Gerais (FAPEMIG) and Coordenação de Aperfeiçoamento de Pessoal de Nível Superior (CAPES) for sponsoring this investigation.

\section{References}

[1] El Sohafy, S.M., Metwalli, A.M., Harraz, F.M. and Omar, A.A. (2009) Quantification of Flavonoids of Psidium guajava L. Preparations by Planar Chromatography (HPTLC). Pharmacognosy Magazine, 5, 61-66.

[2] Lin, J., Puckree, T. and Mvelase, T.P. (2002) Anti-Diarrhoeal Evaluation of Some Medicinal Plants Used by Zulu Traditional Healers. Journal of Ethnopharmacology, 79, 53-56. http://dx.doi.org/10.1016/S0378-8741(01)00353-1

[3] Sanches, N.R., Cortez, D.A.G., Schiavini, M.S., Nakamura, C.V. and Filho, B.P.D. (2005) An Evaluation of Antibacterial Activities of Psidium guajava (L.). Brazilian Archives of Biology and Technology-An International Journal, 48, 429-436. http://dx.doi.org/10.1590/S1516-89132005000300014

[4] Lozoya, X., Reyes-Morales, H., Chávez-Soto, M.A., Matínez-García, M.C., Soto-González, Y. and Doubova, S.V. (2002) Intestinal Anti-Spasmodic Effect of a Phytodrug of Psidium guajava folia in the Treatment of Acute Diarrheic Disease. Journal of Ethnopharmacology, 83, 19-24. http://dx.doi.org/10.1016/S0378-8741(02)00185-X

[5] Carvalho, A.A.T., Sampaio, M.C.C., Melo, A.F.M., Sampaio, F.C., Sena, K.X.F.R., Chiappeta, A.A. and Higino, J.S. (2002) Atividade Antimicrobiana in Vitro de Extratos Hidroalcoólicos Psidium guajava L. Sobre Bactérias GramNegativas. Acta Farmacéutica Bonaerense, 21, 255-258.

[6] Gutiérrez, R.M.P., Mitchell, S. and Solis, R.V. (2008) Psidium guajava: A Review of Its Traditional Uses, Phytochemistry and Pharmacology. Journal of Ethnopharmacology, 117, 1-27. http://dx.doi.org/10.1016/j.jep.2008.01.025

[7] Suntornsuk, L., Gritsanapunb, W., Nilkamhankb, S. and Paochomb, A. (2002) Quantitation of Vitamin C Content in Herbal Juice Using Direct Titration. Journal of Pharmaceutical and Biomedical Analysis, 28, 849-855. http://dx.doi.org/10.1016/S0731-7085(01)00661-6

[8] Sousa, C.M.M., Silva, H.R., Vieira Jr., G.M., Ayres, M.C.C., Costa, C.L.S., Araújo, D.S., Cavalcante, L.C.D., Barros, E.D.S., Araújo, P.B.M., Brandão, M.S. and Chaves, M.H. (2007) Fenois Totais e Atividade Antioxidante de Cinco Plantas Medicinais. Química Nova, 30, 351-355. http://dx.doi.org/10.1590/S0100-40422007000200021

[9] Osawa, K., Miyazaki, K., Shimura, S., Okuda, J., Matsumoto, M. and Ooshima, T. (2001) Identification of Cariostatic Substances in the Cacao Bean Husk: Their Anti-Glucosyltransferase and Antibacterial Activities. Journal of Dental Research, 80, 2000-2004. http://dx.doi.org/10.1177/00220345010800111001

[10] Ferrazzano, G.F., Amato, I., Ingenito, A., De Natale, A. and Pollio, A. (2009) Anti-Cariogenic Effects of Polyphenols from Plant Stimulant Beverages (Cocoa, Coffee, Tea). Fitoterapia, 80, 255-262. http://dx.doi.org/10.1016/j.fitote.2009.04.006

[11] Kale, A., Gawande, S. and Kotwal. S. (2008) Cancer Phytotherapeutics: Role for Flavonoids at the Cellular Level. Phytotherapy Research, 22, 567-577. http://dx.doi.org/10.1002/ptr.2283

[12] Stahl, W. and Sies, H. (1997) Antioxidant Defence: Vitamins E and C. Diabetes, 46, S14-S18. http://dx.doi.org/10.2337/diab.46.2.S14

[13] Chelli-Chentouf, N., Meddah, A.T.T., Mullié, C., Aoues, A. and Meddah, B. (2012) In Vitro and in Vivo Antimicrobial Activity of Algerian Hoggar Salvadora persica L. Extracts against Microbial Strains from Children's Oral Cavity. Journal of Ethnopharmacology, 144, 57-66. http://dx.doi.org/10.1016/j.jep.2012.08.025

[14] Daglia, M., Stauder, M., Papetti, A., Signoretto, C., Giusto, G., Canepari, P., Pruzzo, C. and Gazzani, G. (2010) Isolation of Red Wine Components with Anti-Adhesion and Anti-Biofilm Activity against Streptococcus mutans. Food Chemistry, 119, 1182-1188. http://dx.doi.org/10.1016/j.foodchem.2009.08.037

[15] Ishida, V.F.C., Negri, G., Salatino, A. and Bandeira, M.F.C.L. (2011) A New Type of Brazilian Propolis: Prenylated Benzophenones in Propolis from Amazon and Effects against Cariogenic Bacteria. Food Chemistry, 125, 966-972. http://dx.doi.org/10.1016/j.foodchem.2010.09.089

[16] Domínguez-Perles, R., Moreno, D.A. and García-Viguera, C. (2012) Analysis of the Tumoral Cytotoxicity of Green Tea-Infusions Enriched with Broccoli. Food Chemistry, 132, 1197-1206.

http://dx.doi.org/10.1016/j.foodchem.2011.11.076 
[17] Benavente-Garcia, O. and Castillo, J. (2008) Update on Uses and Properties of Citrus Flavonoids: New Findings in Anticancer, Cardiovascular, and Anti-Inflammatory Activity. Journal of Agricultural \& Food Chemistry, 56, 61856205. http://dx.doi.org/10.1021/jf8006568

[18] Sato, R., Dang, K.M., McPherson, B.G. and Brown, A.C. (2010) Anticancer Activity of Guava (Psidium guajava) Extracts. Journal of Complimentary and Integrative Medicine, 7, 43. http://dx.doi.org/10.2202/1553-3840.1361

[19] WHO (2007) Fight against Cancer: Strategies That Prevent, Cure and Care. WHO Press, World Health Organization.

[20] Brasil (2010) Farmacopeia Brasileira. 5th Edition, Agência Nacional de Vigilância Sanitária, Brasília, 808 p. http://www.anvisa.gov.br/hotsite/cd_farmacopeia/index.htm.

[21] Favilla, M., Macchia, L., Gallo, A. and Altomare, C. (2006) Toxicity Assessment of Metabolites of Fungal Biocontrol Agents Using Two Different (Artemia salina and Daphnia magna) Invertebrate Bioassays. Food and Chemical Toxicology, 44, 1922-1931. http://dx.doi.org/10.1016/j.fct.2006.06.024

[22] Singh, R.P., Chidambara-Murthy, K.N. and Jayaprakasha, G.K. (2002) Studies on the Antioxidant Activity of Pomegranate (Punica granatum) Peel and Seed Extracts Using in Vitro Models. Journal of Agricultural and Food Chemistry, 50, 81-86. http://dx.doi.org/10.1021/jf010865b

[23] Jayaprakasha, G.K., Singh, R.P. and Sakariah, K.K. (2001) Antioxidant Activity of Grape Seed (Vitis vinifera) Extracts on Peroxidation Models in Vitro. Food Chemistry, 73, 285-290. http://dx.doi.org/10.1016/S0308-8146(00)00298-3

[24] CLSI (2006) Performance Standards for Antimicrobial Susceptibility Testing. Clinical and Laboratory Standards Institute, Supplement M100-S16, Wayne.

[25] CLSI (2003) Methods for Dilution Antimicrobial Susceptibility Tests for Bacteria That Grow Aerobically. Clinical and Laboratory Standards Institute, Document M7-A6, Wayne.

[26] Valadares, M.C., Castro, N.C. and Cunha, L.C. (2007) Synadenium umbellatum: Citotoxicidade e danos ao DNA de células da medula óssea de camundongos. Brazilian Journal of Pharmaceutical Sciences, 43, 631-638.

[27] Miladi, H., Slama, R.B., Mili, D., Zouari, S., Bakhrouf, A. and Ammar, E. (2013) Chemical Composition and Cytotoxic and Antioxidant Activities of Satureja montana L. Essential Oil and Its Antibacterial Potential against Salmonella spp. Strains. Journal of Chemistry, 2013, Article ID: 275698. http://dx.doi.org/10.1155/2013/275698

[28] Trindade, S.R., Bonfim, F.G.P., Casali, V.W.D. and Rodrigues-das-Dôres, R.G. (2010) Avaliação de quatro métodos de secagem e doseamento de flavonóides do extrato metanólico de folhas de Psidium guajava em diferentes estágios de maturação. http://www.sic.ufop.br/anais/exibir_trabalho/538

[29] Hussain, H., Krohn, K., Ahmad, V.U., Miana, G.A. and Greend, I.R. (2007) Lapachol: An Overview. Arkivoc, 2007, 145-171. http://dx.doi.org/10.3998/ark.5550190.0008.204

[30] Jiménez, C.D.C., Flores, C.S., He, J., Tian, Q., Schwartz, S.J. and Giusti, M. (2011) Characterisation and Preliminary Bioactivity Determination of Berberis boliviana Lechler Fruit Anthocyanins. Food Chemistry, 128, 717-724. http://dx.doi.org/10.1016/j.foodchem.2011.03.094

[31] Parra, A.L., Yhebra, R.S., Sardiñas, I.G. and Buela, L.I. (2011) Comparative Study of the Assay of Artemia salina L. and the Estimate of the Medium Lethal Dose $\left(\mathrm{LD}_{50}\right.$ Value) in Mice, to Determine Oral Acute Toxicity of Plant Extracts. Phytomedicine, 8, 395-400.

[32] Qian, H. and Nihorimbere, V. (2004) Antoxidant Power of Phytochemical from Psidium guajava Leaf. Journal of Zhejiang University, 6, 643-675.

[33] Tasca, A.P.W. (2008) Efeito do processamento industrial para obtenção de goiabada sobre os compostos antioxidantes e cor. http://www.athena.biblioteca.unesp.br/exlibris/bd/bfa/33004030055P6/2008/tasca_apw_me_arafcf.pdf

[34] Chang, S.T., Wu, J.H., Wang, S.Y., Kang, P.L., Yang, N.S. and Shyur, L.F. (2001) Antioxidant Activity of Extracts from Acacia confuse Bark and Heartwood. Journal of Agricultural \& Food Chemistry, 49, 3420-3424. http://dx.doi.org/10.1021/jf0100907

[35] Nascimento, G.G.F., Locatellil, J., Freitas, P.C. and Silva, G.L. (2000) Antibacterial Activity of Plant Extracts and Phytochemicals on Antibiotic-Resistant Bacteria. Brazilian Journal of Microbiology, 31, 247-256. http://dx.doi.org/10.1590/S1517-83822000000400003

[36] Razak, F.A., Othman, R.Y. and Rahim, Z.H.A. (2006) The Effect of Piper betlle and Psidium guajava Extracts on the Cell-Surface Hydrophobicity of Selected Early Settlers of Dental Plaque. Journal of Oral Science, 48, 71-75. http://dx.doi.org/10.2334/josnusd.48.71

[37] Shruthi, S.D., Roshan, A., Timilsina, S.S. and Sunita, S. (2013) A Review on the Medicinal Plant Psidium guajava. (Myrtaceae). Jounal of Drug \& Therapeutics, 3, 162-168.

[38] Hennebelle, T., Sahpaz, S., Joseph, H. and Bailleul, F. (2008) Ethnopharmacology of Lippia alba. Journal of Ethnopharmacology, 116, 211-222. http://dx.doi.org/10.1016/j.jep.2007.11.044

[39] Seufi, A.M., Ibrahim, S.S., Elmaghraby, T.K. and Hafez, E.E. (2009) Preventive Effect of the Flavonoid, Quercetin, on 
T. V. Braga et al.

Hepatic Cancer in Rats via Oxidant/Antioxidant Activity: Molecular and Histological Evidences. Journal of Experimental \& Clinical Cancer Research, 28, 80. http://dx.doi.org/10.1186/1756-9966-28-80

[40] Batra, P. and Sharma, A.K. (2013) Anti-Cancer Potential of Flavonoids: Recent Trends and Future Perspectives. Biotech, 3, 439-459. 
Scientific Research Publishing (SCIRP) is one of the largest Open Access journal publishers. It is currently publishing more than 200 open access, online, peer-reviewed journals covering a wide range of academic disciplines. SCIRP serves the worldwide academic communities and contributes to the progress and application of science with its publication.

Other selected journals from SCIRP are listed as below. Submit your manuscript to us via either submit@scirp.org or Online Submission Portal.
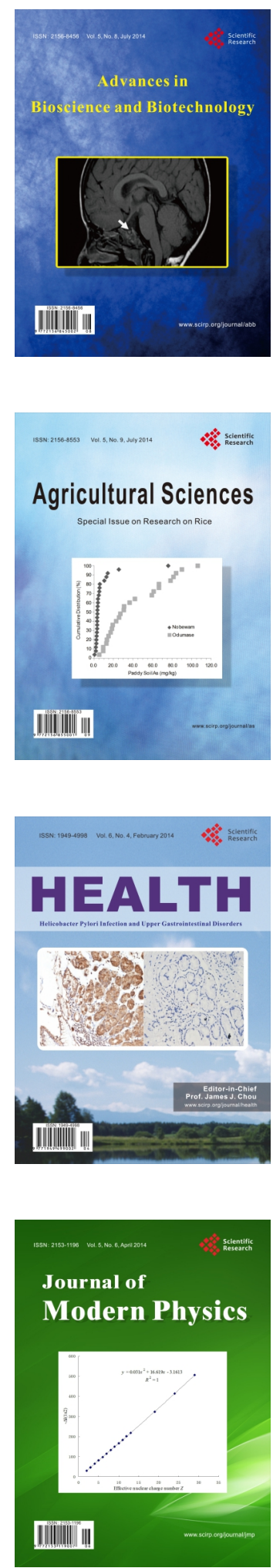
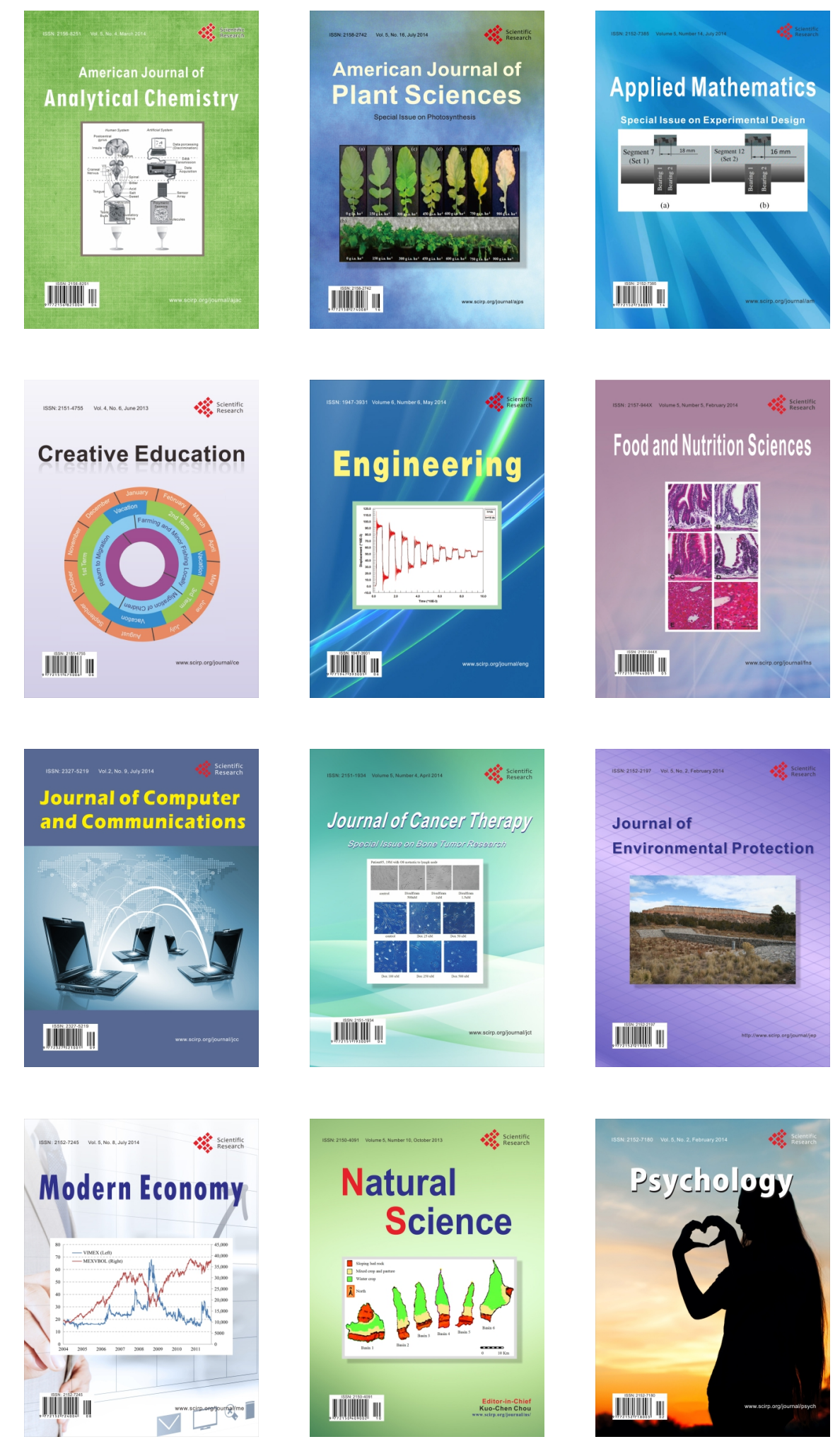